\title{
Survey on Transfusion Laboratory Work in Medical Institutions Participating in the External Quality Control Program for Blood Bank
}

\author{
Jong-Han Lee ${ }^{1}$, Sungwook Song ${ }^{2}$, Sook Won Ryu ${ }^{3}$, and Hyun Ok Kim ${ }^{4}$ \\ 1Department of Laboratory Medicine, Yonsei University Wonju College of Medicine, Wonju; 2Department of Laboratory Medicine, \\ Osan Hankook Hospital, Osan; ${ }^{3}$ Department of Laboratory Medicine, Kangwon National University School of Medicine, \\ Chuncheon; ${ }^{4}$ Department of Laboratory Medicine, Yonsei University College of Medicine, Seoul, Korea
}

\section{Corresponding author:}

Hyun Ok Kim

Department of Laboratory Medicine, Yonsei University College of Medicine, 50-1 Yonsei-ro, Seodaemun-gu, Seoul 03722, Korea

Tel +82-2-2228-2444

Fax +82-2-364-1583

E-mail hyunok1019@yuhs.ac

Received: November 22, 2019

Revised: January 9, 2020

Accepted: January 14, 2020
This is an Open Access article distributed under the terms of the Creative Commons Attribution Non-Commercial License (http://creativecommons.org/licenses/ by-nc/4.0) which permits unrestricted non-commercial use, distribution, and reproduction in any medium, provided the original work is properly cited.
Background: Laboratory tests in blood banks vary with respect to methods, equipment, and quality control according to the hospital's environment.

Methods: We surveyed institutions that regularly participated in the Korean association of external quality assessment using a web-based questionnaire comprising 79 questions regarding transfusion laboratory work.

Results: A total of 84 institutions were surveyed including 17 senior general hospitals, 43 general hospitals, 19 hospitals, four clinics, and one commercial laboratory. ABO cell typing was performed by slide $(63,75.0 \%)$, tube (42, $50.0 \%)$, automated column $(19,22.6 \%)$, and automated microplate $(7,8.3 \%)$ methods. ABO serum typing was performed by tube $(75,89.3 \%)$, automated column $(19,22.6 \%)$, automated microplate $(7,8.3 \%)$, and slide $(7,8.3 \%)$ methods. Irregular antibody screening test and identification test was performed by $58(69.0 \%)$ and $36(42.9 \%)$ institutions, respectively. Irregular antibody screening test and identification test was performed by the column agglutination method in $34(40.5 \%)$ and $26(31.0 \%)$ institutions, respectively. Room temperature saline, albumin, and anti-globulin reagent crossmatching test (three-step method) was the most popular method (48, 57.1\%). The use of anti-globulin reagent in the crossmatching test did not significantly vary according to the size of the hospital. A daily quality control program for ABO, Rh typing, and the crossmatching test was conducted in 58 (69.0\%) institutions.

Conclusions: There were differences in transfusion-related laboratory tests among the institutions. Although this survey included a limited number of institutions, it can be helpful to evaluate the routine laboratory tests and transfusion-related blood bank work in each institution.

(Lab Med Qual Assur 2020;42:40-47)

Key Words Blood transfusion, Blood banks, Laboratory tests, Survey, Quality assessment 
서론

대한임상검사정도관리협회에서 시행하는 신빙도조사사업에 혈액은행 검사가 포함되어 시행되고 있으며, 이런 외부정도관리 프로그램에 참여하면서 각 의료기관은 혈액은행 업무의 질 향상 과 혈액은행 업무의 표준화에 따라 안전한 수혈을 위해서 노력하 고 있다. 수혈 전 검사(pretransfusion tests)는 치명적일 수 있 는 용혈성 수혈 부작용을 예방하기 위한 복합적이고 필수적인 과 정으로 $\mathrm{ABO}$ 및 $\mathrm{D}$ 혈액형검사, 비예기항체선별검사와 교차시험 이 포함된다[1]. 미국 혈액은행협회(American Association of Blood Bank, AABB)에서 발간하고 있는 표준 혈액은행 수혈업무 지침서(AABB Standards for Blood Banks and Transfusion Services)에서는 수혈 전 검사를 하기 위한 검체는 이상적으로는 환자의 성과 이름 그리고 환자 병력번호까지 포함된 바코드가 있 어야 하며, 두 명의 환자 확인자가 필요하다고 제시하고 있다[2]. 또한 국내에서도 수혈 사고의 예방을 위해 2 번의 채혈, 2 명에 의 한 $\mathrm{ABO}$ 혈액형검사, 2 명의 확인에 의한 수혈을 의미한 "2-2-2 안 전 수혈캠페인"이 제안된 이후 많은 기관에서 이를 도입하고 있다 [3]. 그러나 수혈 전 검사는 수혈을 시행하는 의료기관의 혈액은행 에서는 반드시 시행되어야 하는 과정이지만 2018년도 시행한 혈 액은행 외부정도관리 보고에 따르면 $\mathrm{ABO}$ 혈액형 검사에 대한 정 답률이 $99.5 \%-99.8 \%$ 로 아직도 오답기관이 있으며, 참여기관의 $10.1 \%-11.1 \%$ 에서 ABO 혈청형검사를 슬라이드법으로 한다고 보고하였다[4]. 교차시험도 그 정답률이 89.4\%-99.6\%였으며, 그 방법도 다양한 것으로 조사되었다. 따라서 외부신빙도조사사업에 참여한 기관 중 병원의 규모에 따라 검사의 종류가 다르고, 검사방 법에도 차이점이 있기에 이에 대한 현황 파악을 통하여 혈액은행 검사업무 질 향상 노력이 필요할 것으로 생각된다. 이에 저자 등은 대한임상검사정도관리협회에서 실시하고 있는 외부신빙도조사사 업 중 혈액은행 분야에 참여하고 있는 기관인 경우 어느 정도 혈액 은행 검사를 시행하고 있다고 판단되어 전반적인 의료기관 혈액은 행 업무에 대해 설문지조사를 진행하여 혈액은행 업무 전반에 관 한 현황을 파악하고자 하였다. 이 결과는 여러 의료기관의 혈액은 행 검사실에서 참고자료로 활용될 수 있고, 이 자료를 기반으로 표 준방법과 다른 경우 검사실 업무 개선 노력의 일환으로 검사실 수 혈 관련 업무 표준화 사업 등에 활용될 수 있다고 판단되어 이번 연구를 진행하게 되었다.

\section{재료 및 방법}

2019년 3월을 기준으로 대한임상검사정도관리협회 주관 혈액 은행 신빙도조사사업에 참여하고 있는 의료기관을 대상으로 설문
응답을 진행하였다. 설문문항은 대분류 13 분야 중 소분류 79 문항 을 준비하여 설문에 대한 한 가지 이상의 응답을 받아 이를 분석하 였다. 설문조사는 혈액은행 검사분야에 참여하고 있는 기관을 대 상으로 웹베이스 형태의 설문지를 배포하고 결과를 분석하는 방법 을 사용하였다. 본 설문지 결과를 분석하여 추가적으로 각 의료기 관에서 시행 중인 검사현황의 문제점을 분석하였고, 이 자료를 기 반으로 검사실 질 향상 방안을 제시하고자 한다.

\section{결과}

2018년도 혈액은행분과에 참여한 기관은 842 기관이었다. 본 설문조사는 2019년 4월 22일부터 2019년 5월 22일까지 한 달 간 웹베이스 형태로 설문지를 참여기관에 발송하였으며 자발적으로 설문회신을 받았다. 총 84 기관이 회신하여 회신률은 $9.9 \%$ 였다.

\section{1. 설문 참여 의료기관의 특성}

병원의 규모별로는 상급종합병원 17 기관(20.2\%), 종합병원 43 기관(51.2\%), 병원 19 기관(22.6\%), 의원 4 기관(4.8\%), 수탁 검사기관 1 기관(1.2\%)이 참여하였다. 이는 2019년 8월 20일 시 도별 종별 요양기관 현황 통계자료(http://kosis.kr/statHtml/ statHtml.do?orgld= 354 \&tblld=DT_MIRE01)를 근거로 전국 의 상급종합병원 42기관(40.5\%), 종합병원 312기관(13.8\%), 병 원 3,050 기관( $0.6 \%$, 요양병원 포함), 의원 32,169 기관(0.01\%) 대비 각각 $40.5 \%, 13.8 \%, 0.6 \%, 0.01 \%$ 이었다(Fig. 1 ).

회신기관 중 진단검사의학과 전문의가 근무하는 기관은 60 기 관(71.4\%)이었으며, 이 중 혈액은행 전담 진단검사의학 전문의 로 회신한 전문의 수는 27 명으로 $32.1 \%$ 였다. 기관별 병상 수는

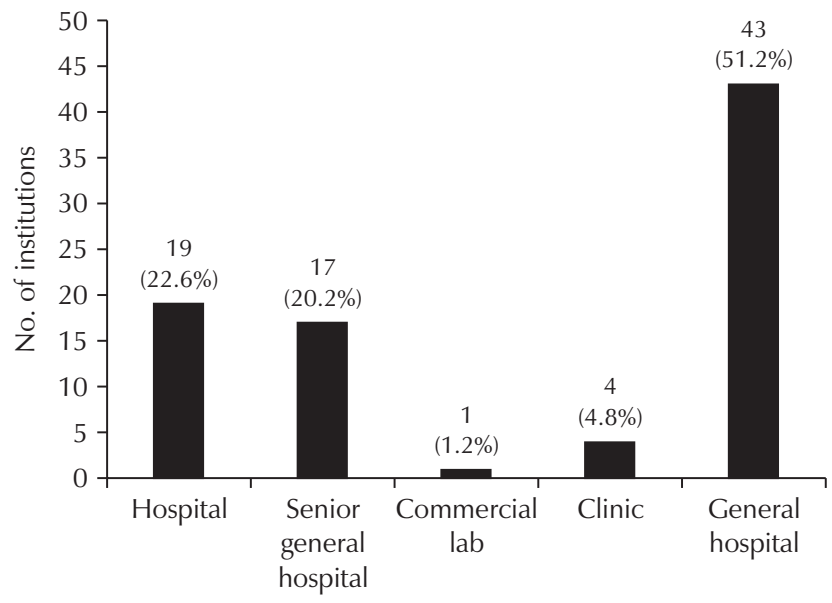

Classification of institutions

Fig. 1. Proportion of institutions in this survey. 
100-300병상 미만 규모의 병원이 25기관(29.8\%), 300-500병 상 미만 17 기관(20.2\%), 800-1,000병상 미만 12 기관(14.3\%), $500-800$ 병상 미만 10 기관(11.9\%), 1,000 병상 이상 9 기관 $(10.7 \%)$ 순으로 많았다. 의료기관의 상근직 진단검사의학과 전 문의 수는 1 인인 기관이 30 기관이었으며( $35.7 \%)$, 없는 기관도 18 기관이었다( $21.4 \%$ ). 4 인의 전문의가 근무하는 기관은 13 기관 (15.5\%), 2 인 전문의 6 기관(7.1\%), 3 인 전문의 5 기관 $(6.0 \%)$ 순 으로 많았고, 혈액은행 전담 임상병리사 수는 1 인 미만(25.0\%), 1 인(29.8\%), 2인(17.9\%), 3인(13.1\%)이었다. 2018년 농축적혈구 혈액제제 출고 수는 평균 25,839단위(표준편차=59,232)로 수혈 이 이루어지지 않는 기관부터 최대 355,600 단위를 사용하는 것으 로 차이가 컸다.

\section{2. 혈액은행의 보유장비(현재 사용 중인 장비)}

참여기관의 반수 이상이 보유한 장비로는 혈액은행전용냉장고 (72, 85.7\%), 해동용 온수조 $(56,66.7 \%)$, Serofuge (66, 78.6\%), 혈액은행전용냉동고 $(56,66.7 \%)$, 혈소판교반기 $(51,60.7 \%)$ 순 이었으며, 자동화혈액은행장비(28, $33.3 \%)$, 혈구세척기( 27 , $32.1 \%)$, 혈액성분채집기( $26,31 \%)$, 헌혈용 혈액혼합기(22, $26.2 \%)$ 는 반수 이상이 보유하지 않는 장비로 확인되었다.

\section{3. 수혈 관련 검사 원내 현황}

\section{1) 수혈용 검사 채혈 튜브의 종류}

$\mathrm{ABO}, \mathrm{D}$ 혈액형검사에 이용되는 튜브는 ethylenediaminetetraacetic acid (EDTA) 튜브(72, 85.7\%)를 주로 쓰고 있었으 며, plain 튜브(30, 35.7\%), serum separating tube (SST; 16,

Table 1. Type of tube used for ABO, Rh typing, and crossmatching test

\begin{tabular}{lcc}
\multicolumn{1}{c}{ Type of tube } & $\begin{array}{c}\text { ABO, Rh } \\
\text { test tube }\end{array}$ & $\begin{array}{c}\text { Cross- } \\
\text { matching } \\
\text { test tube }\end{array}$ \\
\hline Ethylenediaminetetraacetic acid tube & $72(85.7)$ & $47(56.0)$ \\
\hline Plain tube & $30(35.7)$ & $46(54.8)$ \\
\hline Serum separating tube & $16(19.0)$ & $19(22.6)$ \\
\hline Citrate tube & $2(2.4)$ & $1(1.2)$ \\
\hline Heparin tube & $1(1.2)$ & $1(1.2)$ \\
\hline Not use & - & $3(3.6)$ \\
\hline Other & $2(2.4)$ & $2(2.4)$ \\
\hline No response & - & $2(2.4)$ \\
\hline
\end{tabular}

Values are presented as case (\%). The same institution may use more than one type of tube.
$19.0 \%)$ 를 사용하고 있었다. 항응고제 튜브로 sodium citrate 튜 브(2, 2.4\%), heparin 튜브(1, 1.2\%)를 사용한다고 보고한 기 관도 있었다(Table 1). 교차시험용 검체 채혈은 EDTA 튜브(47, $56.0 \%)$, plain 튜브(46, 54.8\%), SST 튜브(19, 22.6\%)가 주로 사용되고 있었다(Table 1).

\section{2) $A B O, D$ 혈액형검사}

"ABO 혈액형 검사결과가 없는 환자(초진 환자)의 경우 $\mathrm{ABO}$ 혈액형검사용 검체와 교차시험용 검체를 분리하여 두 번의 채혈 을 하는가?"의 응답에는 61 기관(72.6\%)이 두 번의 채혈을 진행 중이라고 답하였고 14 기관(16.7\%)은 그렇지 않다고 응답하였 다. $\mathrm{ABO}$ 혈액형 검사결과가 없는 환자의 혈액형검사 시 2 회 채혈 을 하는 기관은 상급종합병원 15 기관(88.2\%), 종합병원 34 기관 (79.1\%), 병원 13 기관(68.4\%), 의원(수탁검사기관 포함) 0 기관 (0\%)이었다.

$\mathrm{ABO}$ 혈액형 혈구형검사는 슬라이드법( $63,75.0 \%)$, 시험 관법 $(42,50.0 \%)$, 자동화 원주응집법 $(19,22.6 \%)$, 자동화 microplate법 $(7,8.3 \%)$ 순으로 나타났다(Table 2). ABO 혈액 형 혈청형검사는 시험관법 $(75,89.3 \%)$, 자동화 원주응집법( 19 , $22.6 \%)$, 자동화 microplate법 $(7,8.3 \%)$, 슬라이드법( $7,8.3 \%)$ 순이었다(Table 2).

$\mathrm{ABO}$ 혈구형검사와 혈청형검사를 동시에 시행하는지에 대한 질문에는 대다수의 기관이 그렇다고 답하였지만(76, $90.5 \%)$, 혈 청형검사를 시행하지 않는 기관이 8 기관(9.5\%)으로 조사되었다. 혈액원에서 공급되는 적혈구 농축액에 대해 $\mathrm{ABO}$ 혈액형을 전수 확인하는 기관은 67 기관(79.8\%)이었으며 주로 슬라이드법(65, $77.4 \%)$ 으로 확인하고 있었다. 혈액원에서 공급되는 신선동결 혈 장에 대해 $\mathrm{ABO}$ 혈액형을 전수 확인하는 기관은 47 기관(56.0\%) 이었으며 주로 확인하는 방법은 슬라이드법 $(49,58.3 \%)$ 이었다.

Table 2. Methods used for ABO cell typing and serum typing

\begin{tabular}{lcc}
\hline \multicolumn{1}{c}{ Methods } & $\begin{array}{c}\text { ABO cell } \\
\text { typing }\end{array}$ & $\begin{array}{c}\text { ABO serum } \\
\text { typing }\end{array}$ \\
\hline Slide method & $63(75.0)$ & $7(8.3)$ \\
\hline Tube method & $42(50.0)$ & $75(89.3)$ \\
\hline Automated column method & $19(22.6)$ & $19(22.6)$ \\
\hline Automated microplate method & $7(8.3)$ & $7(8.3)$ \\
\hline Manual column method & $4(4.8)$ & $4(4.8)$ \\
\hline Other & $1(1.2)$ & $1(1.2)$ \\
\hline No response & $1(1.2)$ & $2(2.4)$ \\
\hline
\end{tabular}

Values are presented as case (\%). The same institution may use more than one method. 
$\mathrm{ABO}$ 혈액형 아형검사를 시행하는 기관은 23 기관(27.4\%)이었 으며, 실시하지 않는 기관은 56기관(66.7\%)이었다. 아형검사에 활용되는 anti-H (Ulex europaeus) 검사는 24기관(28.6\%)이 시 행하고 있었다. D 혈액형검사는 슬라이드법(57, 67.9\%), 시험관 법(48, $57.1 \%)$, 자동화장비법( $17,20.2 \%)$ 순으로 검사하고 있었 다.

$\mathrm{D}$ 혈액형검사에서 응집을 보이지 않는 경우, 약-D검사를 시행 하는 기관은 71 기관(84.5\%)으로 많은 기관이 시행하고 있었다. D 이외의 Rh 아형(예, C, C, E, e)의 항원검사는 27 기관(32.1\%)에서 시행하고 있었다. $\mathrm{ABO}$ 와 D 혈액형 유전자형검사는 4기관(4.8\%) 에서만 시행하고 있었다.

\section{3) 교차시험}

원내에서 가장 많이 시행하고 있는 교차시험방법의 단일 선택 질문에는 3단계 법으로 알려진 실온식염수법+알부민법+항글로불 린법(48, 57.1\%)이었고, 실온식염수법( $15,17.9 \%)$, 자동화법(5, $6.0 \%$ ), 저이온강도식염수법(low ionic strength salt solution, LISS) $+37^{\circ} \mathrm{C}$ 가온법+항글로불린법 $(4,4.8 \%)$ 순이었다(Table 3). 한 가지 방법 이상의 교차시험방법의 설문에는 실온식염수법(40, $47.6 \%)$, 실온식염수법+알부민법+항글로불린법( $36,42.9 \%)$, 알 부민법(35, 41.7\%), 항글로불린법(31, 36.9\%) 등의 순서로 활용 중임이 확인되었다. 비예기항체선별검사를 진행하고 실온식염수 법을 시행하는 기관은 21 기관(25.0\%)이었다. LISS법을 시행하 는 기관은 14 기관( $16.7 \%)$ 이었다. 교차시험방법은 시험관법을 가 장 많이 시행하고 있었으며(67, 79.8\%), 원주응집법( $15,17.9 \%)$, 자동화법 $(5,6.0 \%)$ 등으로 시행하고 있었다. 직접항글로불린검사

Table 3. Methods used for the crossmatching test

\begin{tabular}{lc}
\hline \multicolumn{1}{c}{ Methods } & Case (\%) \\
\hline $\begin{array}{l}\text { Room temperature saline+albumin+anti-human } \\
\text { globulin method }\end{array}$ & $48(57.1)$ \\
\hline Room temperature saline method & $15(17.9)$ \\
\hline Automated method & $5(6.0)$ \\
\hline LISS $+37^{\circ} \mathrm{C}$ saline+anti-human globulin method & $4(4.8)$ \\
\hline LISS & $3(3.6)$ \\
\hline $\begin{array}{l}\text { Room temperature saline+anti-human globulin } \\
\text { method }\end{array}$ & $2(2.4)$ \\
\hline Room temperature saline+albumin method & $1(1.2)$ \\
\hline Not use & $2(2.4)$ \\
\hline Other & $7(8.3)$ \\
\hline No response & $5(6.0)$ \\
\hline
\end{tabular}

Abbreviation: LISS, low ionic strength salt solution.
시 immunoglobulin G (IgG)뿐 아니라 보체도 검출하는 시약을 이용 중인 기관은 55 기관(65.5\%)이었다. 또한 새로운 검체를 채 취하기 전 기존 검체를 사용할 수 있는 최대허용기간에 대한 설문 에는 채혈 이후 3일까지가 47 기관(56.0\%)으로 가장 많았고, 채혈 이후 1 일까지 19 기관(22.6\%), 채혈 이후 2일까지가 7 기관(8.3\%) 이었다.

\section{4) 비예기항체검사}

비예기항체선별검사의 경우 58기관(69.0\%)에서 원내 검사 실에서 검사하고 있었으며, 13 기관(15.5\%)은 외부 의뢰, 8 기관 (9.5\%)은 시행하고 있지 않았다. 비예기항체선별검사는 원주응집 법으로 시행하고 있는 기관이 34 기관(40.5\%)이었고 자동화 기기 를 사용하고 있는 기관도 17 기관(20.2\%)이었다(Table 4). 비예기 항체동정검사를 병원에서 시행하고 있는 기관은 36기관(42.9\%) 이었으며, 31 기관(36.9\%)은 수탁검사기관에 의뢰하였고, 검사를 시행하고 있지 않다고 회신한 기관은 11 기관(13.1\%)이었다. 비예 기항체동정검사의 방법으로는 26 기관(31.0\%)은 원주응집법으로 검사하고 있었으며, 4 기관(4.8\%)만이 자동화된 장비를 사용하고 있었으며, 7 기관(8.3\%)은 원주응집법과 자동화된 장비를 이용한 검사를 혼용하고 있었다. 25 기관(29.8\%)에서는 비예기항체검사 시 항상 자가대조를 확인하고 있다고 응답하였다.

\section{4. 혈액안전감시체계 및 기타 업무 관련}

52 기관(61.9\%)은 혈액안전감시체계에 가입하여 정기적으로 보고하고 있었으며, 21 기관(25.0\%)은 혈액안전감시체계에 가 입하고 있지 않았다. 45 기관(53.6\%)은 혈액관리료를 받고 있었 으며, 25기관(29.8\%)은 혈액관리료를 받고 있지 않았다. 혈액관 리료 미수급의 사유는 다양한 편으로, 주요 원인으로는 혈액은 행 전담 임상병리사의 부재(14,16.7\%), 혈소판교반기 미비(12,

Table 4. Methods used for the irregular antibody screening test

\begin{tabular}{lc}
\hline \multicolumn{1}{c}{ Methods } & Case (\%) \\
\hline Column agglutination & $34(40.5)$ \\
\hline Automated column agglutination & $17(20.2)$ \\
\hline $\begin{array}{l}\text { Mixed test of column agglutination and } \\
\text { automated column agglutination }\end{array}$ & $8(9.5)$ \\
\hline $\begin{array}{l}\text { Microplate method } \\
\text { Mixed test of column agglutination and } \\
\text { microplate method }\end{array}$ & $4(4.8)$ \\
\hline Other & $1(1.2)$ \\
\hline No response & $24(3.6)$ \\
\hline
\end{tabular}

The same institution may use more than one method. 
$14.3 \%)$, 혈액전용냉동고 미비( $11,13.1 \%)$, 전문의 인력 부족( 10 , $11.9 \%)$ 등의 순이었다. 혈액 출고 이후 관분절 보관을 하는 혈액 제제의 종류를 묻는 설문에는 농축적혈구제제는 74 기관(88.1\%), 신선동결 혈장제제는 33 기관(39.3\%), 혈소판제제는 32 기관 (38.1\%), 동결침전제제는 14 기관(16.7\%)이 보관한다고 응답하 였다. 관분절 보관의 기간은 다양하여 3 일 미만 2 기관(2.4\%), 3일 에서 5일 미만 0 기관(0\%), 5일에서 7일 미만이 12 기관(14.3\%), 7 일에서 10 일 미만이 20 기관(23.8\%), 10 일에서 14 일 미만 11 기 관(13.1\%), 14 일에서 한 달 미만이 17 기관(20.2\%), 한 달 이상 15 기관(17.9\%)으로 확인되었다. 수혈 전 검사에 이용이 가능한 검체의 최대기간은 채혈 이후 1 일 이내(37기관, $44.0 \%), 2$ 일 이내 (3기관, $3.6 \%$ ), 3일 이내(32기관, $38.1 \%)$, 5일 이내(0기관, $0 \%$ ), 7일 이내(1기관, $1.2 \%)$, 기타(7기관, $8.3 \%$ ), 무응답(4기관, $4.8 \%)$ 이었다. 수혈검사용 혈액은 최소 며칠간 보관하는지에 대한 설문 에는 14 일에서 한 달 사이가 가장 많아 21 기관(25.0\%)이 응답하 였고, 그 다음으로는 7 일에서 10 일 미만이 17 기관(20.2\%), 5일에 서 7일 미만으로 11 기관(13.1\%)이 응답하였다. 원내 수혈관리위 원회 정기회의에 관한 설문에는 위원회가 구성되어 있으며 정기 회의를 개최하는 55기관(65.5\%), 15 기관(17.9\%)은 위원회가 구 성되어 있지 않고 정기회의를 하는지 모른다고 응답하였고, 5 기관 (6.0\%)은 위원회가 구성되어 있지 않으나 필요시 회의를 한다고 응답하였다.

\section{5. 기타 수혈 관련 검사}

기타 수혈 관련 검사항목은 먼저 "A형 아형을 구별하기 위 한 항-A1을 원내에서 활용하는가?"를 설문하였는데, 29 기관 (34.5\%)만이 사용하고 있다고 답하였다. 직접항글로불린검사 (direct anti-human globulin test)는 주로 다가 항글로불린 혈청(polyspecific antiglobulin reagents)을 사용하고 있었으 며(34, 40.5\%), anti-IgG monospecific 항글로불린혈청은 17 기관(20.2\%)이 사용하고 있었다. 또한 원주응집법(34, 40.5\%) 을 전통적인 시험관법 $(12,14.3 \%)$ 보다 더 많이 활용하고 있었 다. Dithiothreitol 등을 처리하여 자가응집의 분해를 하거나 immunoglobulin M, IgG 항체 식별에 활용하는 기관은 16 기 관(19.0\%)이었다. 항체용출(elution) 시행기관은 가열법 5 기관 (6.0\%), digitonin-acid법 3기관(3.6\%), ether법 2기관(2.4\%)이 시행 중으로 조사되었다. 한냉자가흡착(cold autoadsoprtion) 도 11 기관(13.1\%)만이 시행 중이었으며, ZZAP 시약을 활용한 항 체흡착(antibody adsorption)검사의 경우 10기관(11.9\%)만 시 행 중이었다. 항체해리(antibody dissociation)의 경우 glycine acid법으로 5기관(6.0\%), chloroquine법으로 1 기관(1.2\%)이 시행 중이었다. 도나쓰-랜드스타이너 검사(Donath-Landsteiner test)는 9 기관(10.7\%)만이 시행 중이었으며, 한냉응집소검사 (cold agglutinin test)의 경우 28기관(33.3\%)이 시행 중이었 고 44기관(52.4\%)은 시행하지 않았다. 혈액형물질분비검사 (secretor test)의 경우 전체의 6기관(7.1\%)만이 시행 중이었다.

\section{6. 대량수혈}

대량수혈은 성인에서 24시간 이내에 8-10단위의 적혈구제제 가 수혈되거나 1시간 내에 4-5단위의 적혈구제제가 수혈되는 경 우로 적혈구, 혈장, 혈소판을 1:1:1의 비율로 동시 출고하는 가이 드라인 등을 활용하여 기관별로 프로토콜 활용에 대한 설문을 하 였다. 관련한 응답으로 원내 대량수혈지침이 있는 기관은 36 기관 (42.9\%)이었으며, 없는 기관은 25기관(29.8\%)이었고, 지침은 있 으나 활용되지 않는 기관의 수는 15 기관(17.9\%)으로 확인되었다.

\section{7. 성분채집술}

혈장교환술의 주 관여자의 직종을 묻는 설문에는 간호사 13 기 관(15.5\%), 기타 9 기관(10.7\%), 임상병리사 6기관( $7.1 \%)$, 전공 의 5 기관(6.0\%), 전문의 3 기관(3.6\%)의 순으로 확인되었다. 조혈 모세포채집의 주 관여자의 경우 간호사 10 기관(11.9\%), 기타 9 기관(10.7\%), 임상병리사 7 기관(8.3\%), 전공의 1 기관(1.2\%), 전 문의 1 기관(1.2\%)의 순으로 확인되었다. 혈장교환술에 이용하 는 장비로는 Spectra Optia가 15 기관(17.9\%), 기타 장비 8기관 (9.5\%), COBE spectra가 4기관(4.8\%), Amicus는 3기관(3.6\%), ComTec은 1 기관(1.2\%), Hemonetics MCS+가 1 기관(1.2\%) 순으로 나타났다. 조혈모세포채집에 이용하는 장비로는 Spectra Optia가 11 기관(13.1\%), 기타 장비 9 기관(10.7\%), Amicus는 4 기관(4.8\%), COBE spectra는 3기관(3.6\%), ComTec은 1기관 (1.2\%) 순으로 많았다. 2018년 혈장교환술의 시행 횟수의 경우 중앙값 84 건 정도이며 최소 11 건에서 최대 2,159건이었다. 혈장 교환술은 성분채혈실과 같은 특정한 장소에서 시행되는지에 대 한 설문에는 20 기관(23.8\%)에서 그렇다고 하였고 6 기관(7.1\%) 은 아니었다. 혈장교환술 장소 관련 통계는 51기관(60.7\%)은 응 답이 없었다. 성분채혈실과 같은 특정한 장소에서 시행되지 않는 다면 주로 중환자실(intensive care unit) 12 기관(14.3\%), 기타 11 기관(13.1\%), 일반병동 5 기관(6.0\%) 순으로 시행되고 있었다. 성분채혈실 등에서 진행되지 않을 때 부서 설문의 경우 61 기관 (72.6\%)은 응답이 없었다. 혈장교환술 운영의 경우 진단검사의학 과 소속인지에 대한 설문에는 20기관(23.8\%)은 진단검사의학과 소속이며, 기타 10 기관( $11.9 \%)$, 혈액종양내과 등 다른 임상과에 서 시행하고 있는 경우가 2기관(2.4\%)이었다. 


\section{8. 정도관리}

정도관리를 위한 자가제조 혈구를 사용하는 기관은 43 기관 $(51.2 \%)$ 이었으며, 35 기관(41.7\%)는 이용하지 않았다. 상품화된 정도관리 제품을 이용하는 기관은 52 기관(61.9\%)이었으며, 25 기 관(29.8\%)은 이용하지 않고 있었다. ABO, D 혈액형검사, 교차시 험의 결과보고를 위한 정도관리를 매일 시행하는가에 대한 설문 에는 58기관(69.0\%)은 매일 시행 중이었으며, 외부정도관리만 진 행한다고 응답한 기관은 16 기관(19\%)이었으며, 5일 초과 주기로 정도관리 진행 중인 기관도 3 기관(3.6\%) 해당되었다. 비예기항체 검사 관련 정도관리의 경우 매일 주기로 시행하는 기관은 49 기관 (58.3\%)이었으며, 특별한 정도관리를 시행하지 않는 기관은 6기 관(7.1\%)이었다. 이외에도 5일 초과 주기 및 2-4일 주기로 비예 기항체검사 정도관리 진행 중인 기관은 각각 3 기관(3.6\%)이었다.

\section{9. 환자 확인방법}

“환자 확인을 위한 노력으로 환자의 병력번호, 성명, 생년월일 등 두 가지 이상의 정보로 환자 확인을 진행 중인가?”에 대한 설 문에는 80 기관(95.2\%)에서 확인하고 있다고 응답하였다. 환자 확인을 위한 전자장비 지원시스템 설문에는 바코드시스템을 활 용하는 기관은 48 기관(57.1\%)이고, 검체 바뀜, 수혈사고 예방을 위한 전자장비 활용은 9 기관(10.7\%) 만이 이용 중이었다. 손목 밴드만 수기로 진행하고 전자장비 지원시스템이 없는 기관은 33 기관(39.3\%)으로 더 많았으며, 손목밴드 및 전자장비 지원시스 템이 모두 없는 기관은 4기관(4.8\%)이었고, RFID 시스템(radiofrequency identification system)을 활용하는 기관은 1 기관 $(1.2 \%)$ 이었다.

\section{0. 방사선 조사기}

방사선 조사기를 원내에 보유하고 있는 기관은 22기관(26.2\%) 이 있다고 응답하였고, 33기관(39.3\%)은 없다고 응답하였 다. 방사선 조사기의 종류로는 $\mathrm{IBL}-437 \mathrm{C}$ 이 11 기관(13.1\%), Gammacell Elan 3000이 10기관(11.9\%), Biobeam GM8000 이 2 기관(2.4\%)이었다. 혈액 X선 조사기를 사용하는 기관은 없었 다.

\section{1. 기관 내 헌혈혈액원 운영}

기관 내 헌혈혈액원을 운영하고 있는가에 대한 설문에는 23 기 관(27.4\%)이 운영 중이라고 응답하였으며, 47 기관(56.0\%)은 운 영 안함으로 답하였고, 4 기관(4.8\%)은 휴원 중이라고 응답하였 다.

\section{2. 혈소판 혼주}

혈소판 혼주는 어느 부서에서 주로 준비되는가에 대한 설문 에는 응답기관 총 84 기관 중 45 기관의 응답이 있었다. 이 중 병 동 15 기관( $17.9 \%)$, 진단검사의학과 13 기관( $15.5 \%)$, 기타 8 기관 (9.5\%), 공급혈액원의 성분채혈혈소판만 이용 중 7 기관(8.3\%), 외래 2 기관(2.4\%)의 응답 순으로 확인되었다. 44 기관(52.4\%) 은 혈소판 혼주관련 문의에 응답이 없었다. 혈소판 수혈 관련 성 분채혈혈소판제제와 농축혈소판의 사용빈도현황은 농축혈소판 제제가 성분채혈혈소판제제보다 많다가 35 기관(41.7\%), 무응답 35 기관(41.7\%), 기타 6기관(7.1\%), 정확히 알기 어렵다 2기관 (2.4\%), 성분채혈혈소판제제와 농축혈소판제제가 유사하다가 1 기관(1.2\%)으로 확인되었다.

\section{3. 백혈구제거적혈구제제}

“백혈구제거적혈구제제는 주로 어떻게 준비되는가?”의 설문에 는 공급혈액원에서 입고된 보존전백혈구제거적혈구(prestorage leukocyte-reduced RBC)만을 활용한다가 27기관(32.1\%)으로 가장 높았고, 그 다음은 무응답 25 기관(29.8\%), 병동에서 백혈구 제거 필터링만 진행한다가 16 기관(19.0\%), 공급혈액원에서 입 고된 보존전백혈구제거적혈구(prestorage leukocyte-reduced $\mathrm{RBC}$ )를 주로 활용하고 병동에서 일부 진행하는 경우가 14 기관 $(16.7 \%)$ 으로 확인되었다.

\section{고찰}

최근 국내 전국단위의 설문을 통한 수혈 전 검사현황을 파악하 기 위한 노력은 2015년 질병관리본부 정책용역연구 과제인 “수 혈자 안전성 확보를 위한 지역 거점 의료기관(수혈 전 검사 및 교 육 자문) 운영방안 연구”의 일환으로 중소병의원의 수혈 전 검사 와 장비 보유현황을 파악하였던 연구가 있었다[5]. 본 연구는 설문 규모를 보다 확대하고 구체적인 검사 수행 및 검사실 운영실태 등 을 웹베이스 형태의 설문을 통해 수혈검사 관련 현황을 파악하고 자 하였다. 우선 혈액형검사에는 항응고제가 있는 튜브에 채혈하 는 기관이 제일 많았지만 교차시험용으로는 항응고제가 있는 채 혈 튜브와 항응고제가 없는 튜브에 채혈하는 기관이 비슷하여, 혈 액형검사용 채혈은 혈장으로, 교차시험은 혈청을 선호하는 것으로 생각되었다. “ABO 혈액형 검사결과가 없는 환자(초진 환자)의 경 우 $\mathrm{ABO}$ 혈액형검사용 검체와 교차시험용 검체를 분리하여 두 번 의 채혈을 하는가?"의 응답에는 기관규모가 클수록 두 번의 채혈 을 진행하는 것으로 보였고, 중소의료기관에서는 그렇지 않다고 응답한 기관이 많아서 환자 확인을 위한 노력이 더욱 필요하리라 생각되었다. 그리고 검체 바뀜, 수혈사고 예방을 위한 전자장비 활 
용은 9기관(10.7\%)만이 이용 중이었는데, 향후 전자장비 등을 활 용한 환자 확인 오류를 방지하는 적극적인 방안이 모색되어야 할 것으로 생각되었다. 이는 잘못된 환자 인지로 부적절한 수혈이 이 루어지는 경우 매우 심각한 위해로 작용할 수 있기 때문이다[6-9]. $\mathrm{ABO}$ 혈액형 혈구형 검사방법의 경우 판독 민감도를 높이고 감염 예방을 위하여 슬라이드법의 사용이 줄고 있는 외국과 다르게 국 내에서는 슬라이드법이 아직 널리 쓰이고 있었다[10]. 또한 중소 의료기관을 대상으로 진행했던 기존 국내 연구에서 슬라이드법 활 용은 74.3\%로 조사되었는데[5], 이번 조사에서도 ABO 혈액형 혈 구형검사의 경우 63기관(75.0\%)으로 그 결과가 유사하였다.

교차시험의 경우 검사방법이 7종류로 조사되었다. 가장 많 이 사용하는 방법이 실온식염수법+알부민법+항글로불린법(48, $57.1 \%)$ 이었는데, 기관별 항글로불린검사까지 진행하는 정도의 수준은 기존 국내 연구 $84.6 \%$ 와 유사한 수준이었다[5]. 항글로 불린시약 사용 교차시험의 경우 기관의 규모에 따른 유의한 차이 는 없었다. 그러나 LISS를 사용하면서 항글로불린 단계까지 시행 하지 않고 있는 기관이 보고되는 등 교차시험에서도 전국단위의 표준검사방법의 제시가 필요할 것으로 생각된다. 그 외 교차시험 방법과 비예기항체검사 방법은 전통적인 시험관법 외에 수기 또 는 자동화 원주응집법이 많이 활용되고 있었으며, 비예기항체검 사는 58기관(69.0\%)은 원내 검사실에서 수행 중이라고 보고하여 2016년에 조사된 기관 수보다 3배 이상 원내 수행비율이 증가한 수치로 원주응집방법의 도입이 의료기관에 빠르게 이루어지고 있 음을 알 수 있었다[5]. 비예기항체동정검사의 경우 비예기항체선 별검사 방법보다는 자동화된 장비 이용은 아직 낮은 편이었다. 혈 액관리료 미수급의 주요 원인으로는 혈액은행 전담 임상병리사의 부족, 혈소판교반기 부족, 혈액전용 냉동고 부족, 전문의 인력 부 족 등의 원인으로 확인되어 의료기관의 혈액관리료 수급률을 높 이기 위한 인력 및 장비 지원의 필요성이 있어 보였다. 기타 업무 관련하여 기관마다 출고된 혈액의 관분절 보관의 기간은 7 일에서 30 일까지 다양하게 보관되고 있어 수혈 후 이상반응을 확인하기 위해 보관하는 관분절 보관 이유를 정확히 이해시키고, 기간을 제 안해 줄 필요성이 있을 것으로 여겨진다. $\mathrm{AABB}$ 기술지침에 의하 면 수혜자의 혈액 검체와 기증자의 적혈구 검체는 냉장상태에서 적어도 매회 수혈 이후 7 일까지는 보관되어야 한다고 제시되었다 [2].

대량수혈지침도 절반 이하(36기관, $42.9 \%)$ 의 의료기관에서는 마련되어 있지 않았으며, 성분채집술의 주 관여자의 직종과 장소,
혈액은행 검사의 정도관리 등 기관의 특성에 따라 차이가 많아 이 역시 적절성 검토가 필요하리라 생각되었다.

혈소판 혼주의 경우 개방계에서 이루어지는 경우 조작 후 적어 도 6시간을 초과하지 않도록 가능한 빨리 수혈되어야 한다[11]. 이러한 혈소판 혼주의 시행은 병동, 혈액은행에서 진행하거나 공 급혈액원의 성분채혈혈소판제제만을 이용하는 방법으로 주로 이 루어지고 있었다. 적혈구제제의 백혈구 제거는 공급혈액원, 혈액 은행, 병동에서 각각 이루어지고 있었다. 국민에게 양질의 혈액을 공급한다는 측면에서 이런 특수혈액을 공급하는 공급혈액원의 역 할이 중요하다고 생각되었다. 이번 연구는 총 설문 참여기관의 수 가 84 기관만으로 전체 현황을 충분히 반영하기에는 제한이 있었 다. 설문 참여비율이 적었던 이유로는 연구 관련 충분한 안내 부족 과 개인정보보호법 때문에 설문지를 개인 이메일 등을 활용한 배 포의 제한 및 설문 참여자에게 특별한 보상이 지급되지 않았던 점 등을 생각할 수 있었다. 그리고 이번 연구는 온라인 설문 안내방법 이 혈액은행 외부정도관리 온라인 결과 입력 이후 팝업 안내문으 로 삽입하여 설문 참여를 안내하였으나 팝업화면 특성상 안내문이 사라지기 쉬운 단점이 있었고, 외부정도관리 결과 입력 이후의 연 구 참여는 설문 응답자에게 또 다른 과제 부여로 인식되어 설문 참 여자에게 부담이 될 수 있었다고 생각되었다. 따라서 다음 설문의 준비에는 설문 참여율을 높일 수 있는 세밀한 준비가 필요하리라 판단된다. 그러나 총 79 문항으로 이루어진 설문은 그동안 시행되 었던 설문조사에 비해 자세한 편으로 혈액은행에서 이루어지고 있 는 업무에 대해 조사함으로써 중소 병의원 혈액은행 관련 지침이 부족하다는 점과 혈액은행 검사에 대한 좀 더 정확한 검사방법을 제시해 줄 수 있는 교육자료의 필요성이 있음을 알게 되었고, 수혈 의 안정성 평가에 관련 학회에서도 적극적인 관심이 더 필요할 것 으로 생각되었다. 이번 연구결과가 많은 수는 아니지만 상급종합 병원, 종합병원, 병원, 의원이 모두 포함되어 우리나라 의료기관의 업무현황을 파악할 수 있는 자료를 제시하였다고 생각하며, 기관 별 현황 비교, 정도관리 주기 확인 및 수혈 관련 검사 표준화에 도 움이 되리라 생각된다.

\section{감사의 글}

이 연구 과제는 2019년 대한임상검사정도관리협회 학술연구비 지원에 의해 수행되었으며, 이번 설문에 참여해 주신 분들께 깊은 감사를 드립니다.

\section{REFERENCES}

1. Boisen ML, Collins RA, Yazer MH, Waters JH. Pretransfusion testing and transfusion of uncrossmatched erythrocytes. 
Anesthesiology 2015;122:191-5.

2. Standards Program Committee, American Association of Blood Banks. Standards for blood banks and transfusion services. 25th ed. Bethesda (MD): American Association of Blood Banks, 2014.

3. Cho D, Hyun J, Ryang DW. Prevention of ABO incompatible blood transfusion:'2-2-2 safe blood transfusion campaign'. Korean J Blood Transfus 2013;24:79.

4. Lim YA, Cho HS. Annual report of the Korean Association of External Quality Assessment Service on transfusion medicine (2018). J Lab Med Qual Assur 2019;41:65-74.

5. Lim J, Lim YA, Lim HS, Lim CS, Kim JN, Choi YS, et al. Current status of pretransfusion tests and equipments in small and medium sized hospitals in Korea. Korean J Blood Transfus 2016;27:148-54.

6. Serious Hazards of Transfusion. Annual report 2001-2002: serious hazards of transfusion scheme. http://www.shotuk. org (Accessed March 13, 2020).

7. Dzik WH. Emily Cooley Lecture 2002: transfusion safety in the hospital. Transfusion 2003;43:1190-9.

8. McClelland DB, Phillips P. Errors in blood transfusion in Britain: survey of hospital haematology departments. BMJ 1994;308:1205-6.

9. Sazama K. Reports of 355 transfusion-associated deaths: 1976 through 1985. Transfusion 1990;30:583-90.

10. UK National External Quality Assessment Scheme. UK National External Quality Assessment Scheme for blood transfusion laboratory practice: bi-ennial report 2007-2009. Sheffield: UK National External Quality Assessment Scheme, 2009.

11. Han GS, Park KW, Song EY. Platelets. In: Han GS, Park KW, Song EY, editors. Transfusion medicine. 4th ed. Seoul: Korea Medical Book Publishing Company, 2014:53. 